\title{
PLANNING AND GEOHAZARDS
}

\author{
Gibson, A $D^{1}$ \& Chowdhury, $\mathbf{R}^{2}$ \\ ${ }^{1}$ British Geological Survey, Nottingham, UK \\ ${ }^{2}$ University of Wollongong, New South Wales, Australia
}

\section{INTRODUCTION}

Fifty six papers were accepted for the Geohazards and Planning Theme of the $10^{\text {th }}$ Congress of the International Association for Engineering Geology and the Environment. Authors from sixty different countries successfully submitted papers, with particularly strong representation from China, Brazil, Russia and Turkey (Fig. 1.). Due to the popularity of this Congress theme, it has not been possible to summarise all of the papers accepted, or indeed fully represent the breadth of research contained within individual works. Selected papers are considered here as representative case studies to illustrate state of the art research and developments pertaining to different geohazards (Table 1), and also the topics of risk modelling, urbanization as the cause of hazard, and mitigation techniques.

Figure. 1. Geographical distribution of papers submitted for Planning and Geohazards Theme.

\section{SESSION DISCUSSION}

Most of the discussion centred on the assessment and management of hazard and risk. Increasing frequency of natural disasters was acknowledged as an alarming and challenging development all over the world, especially in less developed nations. It was highlighted that the causes for this are complex. The discussion included anecdotal reports to support an increasing temporal frequency of high magnitude hazard events - a pattern that may be related to climate change and other phenomena. Importantly, population rise means that many areas of urbanization are now encroaching into marginally or entirely unsuitable land. The exposure to hazards and vulnerability of people, housing, industry and infrastructure are increasing. Poor planning and inferior construction in poorer and less developed countries increase their vulnerability and the consequences of hazard events. The discussion concentrated on the fact that, with these two trends, an increase in frequency and magnitude of urban disasters is bound to occur.

Risk 'management' carried out after an event often proves to be inadequate in the short-term and ineffective or even counter-productive in the long-term. Often, significant losses from a natural disaster are followed, after another few years, by a disaster of comparable or greater severity. Thus, there is an urgent need for more innovative approaches to hazard assessment and to risk management. Importantly, urgent consideration must be given to 'preventative risk management'. This should include careful planning for the medium to long-term, strict control on the extent and intensity of development, appropriate instrumentation and monitoring, early warning systems and a variety of engineered solutions to specific problems. Adoption of such measures in advance of the occurrence of potential natural events would, of course, involve significant expenditure but this should be presented as key investment, the benefits of which could be enormous. Conversely, failure to invest will result in lost opportunity and potentially catastrophic loss.

It was broadly agreed that preventative risk management incorporating a variety of tools, techniques and methodologies should be adopted for reducing the frequency and severity of disasters and other adverse natural events. Even for a strategy embracing 'preventive risk management', it is necessary to put in place a reliable hazardvulnerability-consequence framework. It was agreed that engineering geologists have a crucial role in this process. However, to maximise the benefit to the community, engineering geologists must continue to develop new avenues of communication, working alongside planners, economists or politicians.

Table 1. Research Topics of the papers accepted for the Theme Geohazards and Planning

\begin{tabular}{|l|l|}
\hline Geohazard Theme & Paper Number \\
\hline Earthquakes & $\begin{array}{l}106,236,242,256,262,293,305,317,318,361,362,410,424,449,457,563, \\
587,753,760,763\end{array}$ \\
\hline Landslides & $\begin{array}{l}114,154,169,173,324,449,470,502,513,535,624,644,712,779,784,790, \\
796,806,818\end{array}$ \\
\hline Karst & $247,262,282,353,410,449,573,801$ \\
\hline Settlement & $114,262,294,449,465,502,712,786$ \\
\hline Soil erosion & $139,145,449,465,502$ \\
\hline Flooding & $154,282,737,760$ \\
\hline Collapsible soils & $196,294,324$ \\
\hline
\end{tabular}




\begin{tabular}{|l|l|}
\hline Shrink-swell & 410,465 \\
\hline Volcanoes & 114,624 \\
\hline Fissuring & 596 \\
\hline Undermining & 262 \\
\hline Contamination & 293 \\
\hline Radon & 554 \\
\hline
\end{tabular}

\section{EARTHQUAKES}

Twenty papers with a central theme of seismic hazard were submitted. Most concentrate on building seismic hazard scenarios at a city scale, using microzonation and GIS techniques. Maksud Kamal \& Midorikawa (2009) described a microzonation study for Dhaka, Bangladesh. Combining a new geomorphological model with the results of a seismic velocity survey of the city, they were able to define three areas where ground conditions and building height combined to form discrete areas of relatively high risk. The results of their study have been used to support a proposed process to retrofit buildings at particular risk. Similarly, a study by Kocbay \& Orhan (2009) highlighted areas where the weak nature of lake sediments near Lake Efteni, Turkey, resulted in an increased liquefaction potential.

Several studies were presented concerned with establishing ground motion amplification patterns associated with superficial or artificial deposits. Ohta et al. (2009) developed a model utilising borehole records and other information to assess liquefaction potential for the city of Takamstsu, Japan. This study was supported by that of Saito et al. (2009), which described how shallow seismic techniques were used to supplement the borehole information. Their technique determined the S-wave velocity profile of the ground using the response from an artificial seismic source. Although the depth of investigation is limited and reliant upon a fair understanding of the subsurface environment, it is non-invasive, compact and cheap. Results presented showed that S-wave profiles related to channel fill or embankments comprising weathered granite were clearly identifiable.

Rebolledo et al. (2009) described a study centred on the city of Santiago, Chile and sought to understand anomalous patterns of damage observed following a M 7.8 earthquake in 1985. They presented results from a geotechnical and geophysical investigation, which established a clear ground motion amplification pattern in areas where thick ignimbrite and pyroclastic flow deposits were underlain by fine grained soils. Pergalani \& Compagnoni (2009) classified characteristic geological profiles in Lombardia, Italy, according to their likely response to a seismic event. An extensive programme of laboratory testing and modelling of subsurface profiles identified three characteristic successions, of which 'silt with clay' was the most susceptible to ground motion amplification.

Liquefaction of alluvial sediments on the shore of Lake Sapanca, Turkey following the Kocaeli earthquake of 1999 was described by Kanibir et al. (2009). Substantial damage was caused to buildings, lifelines and other structures, many of which were affected by lateral spreading towards the lake. They developed a series of empirical models based upon seismological, topographical and soil property data, which accurately simulated observed ground deformation.

Other researchers drew attention to areas where the seismic hazard may be underestimated and further research is required, often because the regional model of seismicity does not take local conditions into account. Ghanbari \& Jalili (2009) reconsidered the earthquakes affecting the North Tabriz fault, which is rupturing progressively in a westward direction. Their assessment of the seismic history of the fault since the $17^{\text {th }}$ Century suggested a recurrence interval for destructive earthquakes that would justify the microzonation of Tabriz and other cities within Azerbaijan, regions of the Caspian basin and Iran. The related study by Ghanbari et al. (2009) supported this research. Çabalar (2009) considered the possibility that existing seismic models of Gaziantep, Turkey, might underestimate the hazard posed by the Dead Sea Fault Zone as well as the more heavily studied North Anatolian Fault. Jamali et al. (2009) presented a preliminary evaluation of the seismic hazard in Fujairah Emirate and recommend further study.

Fenton (2009) highlighted the need, in many instances, to consider site-specific hazard. He presented a methodology that can be applied when a detailed site study to properly establish the 3D architecture of a rupture system is not feasible. The technique described takes advantage of the fact that, in tectonically active regions, surface faulting often occurs on existing faults, with deformation reducing with distance from the rupture. His paper demonstrated that a rupture zone map, indicating probability and extents of movement, can be made using pre-existing records and, crucially, professional judgement. The maps have been used to communicate the problem to engineers, aiding the design of seismic protection features. As with many papers presented and accepted in this theme, the solution was a pragmatic compromise which seeks to reduce risks using the best available information.

\section{LANDSLIDES AND EROSION}

Landslide specific studies included that of Zhou (2009), who described a case study for the Baota landslide on the banks of the Yangtze River, China. This ancient landslide has been subject to local reactivations since 1984 and poses 
a significant threat to several new developments. An extensive monitoring programme was developed that used several different techniques, with special attention paid to groundwater. Careful monitoring of pore-water pressure, temperature and chemistry revealed a complex relationship between movement, rainfall and the elevation of the river. The Three Gorges Dam has been designed to enable annual fluctuations in water depth of up to $45 \mathrm{~m}$, to allow safe entrapment of flood waters. Aware of the potential impact of this variation in head on the stability of pre-existing landslides, Mo \& Yuhu (2009) carried out a detailed study along a stretch of land containing a selected number of landslides. Computer modelling of slope stability along this stretch under different scenarios was used to inform local development plans.

Zenóbio \& Zuquette (2009) described work to help engineers and planners involved in the expansion of urban zones into unstable, weathered slopes in the Serra de Ouro Preto region in Brazil. They carried out extensive geotechnical mapping and geotechnical testing of materials and combined these with assessments of natural slope instability to produce zoning charts for use by non-geological professionals. The Sao Pedro and Barra Bonita region of Sao Paulo is extensively affected by landslides, gulleying and soil loss. Ferreira \& Pejon (2009) described how an understanding of these issues required an extensive knowledge of the engineering geology and hydrogeology in the three separate watersheds.

\section{KARST}

Schmitz \& Schroeder (2009) presented two case studies of how early involvement in construction projects by engineering geologists has greatly assisted in major construction projects in karst terrains. One of these involved the Soumagne tunnel, part of a new railroad from Brussels, via Liège and Aachen, to Cologne. The tunnel cut through a series of limestones known to show palaeokarst. Site investigation techniques included borehole, geophysical, geotechnical and hydrological measurements, a pilot gallery, microgravimetric measurements and advance drilling. The basic ground model was applied to determine appropriate site investigation and construction techniques to identify potential karst problems for the duration of the construction project.

Török et al. (2009) presented a review of the impact of karst on cities and went on to compare the relative impact of karst in Hungary and Greece. The comparison is a useful one, as it allows comparison between Hungary, affected by a relatively small area (4.4\%) of uncovered karst, as opposed to a country which has nearly a third of its surface area covered by limestone but with a generally subsurface karst. They described the major engineering challenges posed by subsurface karst that often lead to water intrusion, overbreaks, instabilities and other challenges. For the examples presented, they demonstrated that Greek karst is often related to discontinuity-controlled water flow or instability, whereas the karst of Hungary is more closely related to the drawdown of the water table caused by urban expansion. The difficulty of assessing thermal karst, which develops upwards and shows very little surface expression until a collapse occurs, was also described.

Anikeev (2009) carried out a series of experiments to investigate the phenomenon of spalling and fissuring of clay materials, which form caps to many karstic voids and fissures and are the main cause of sinkhole generation in a zone of the pre-glacial Moscow river valley. Through a long-standing research programme they have identified a chain of hydrological, suffosion and stress-relief processes that contribute to karst activity and are contributing to a better understanding of the subsidence in the north-west district of Moscow.

\section{SETTLEMENT AND SUBSIDENCE}

Ruilin (2009) presented an excellent and detailed review of urban land subsidence in China. He showed that at least eleven cities, including Shanghai, Tianjin and Suzhou have had an accumulative subsidence of greater than $1 \mathrm{~m}$ at their subsidence centres. The primary cause of the problem is withdrawal of groundwater by urban and industrial consumers. Although many lessons were leant from these experiences, the author described how the expansion of new industrial cities, currently of "median-size" is expected to lead to similar problems over the next few decades.

A different aspect of subsidence was explored by Ajalloeian et al. (2009). They described ground fissuring related to subsidence in the northern Mahyar plain, Iran, which has caused damage to houses, agriculture and highways for the past thirty years. Although the groundwater extraction, which caused the subsidence, had slowed since 1991, ground fissuring had continued. Using 3D modelling techniques, they were able to establish a relationship between the thicknesses of clay units at depth, with the pattern of surface fissuring.

\section{COLLAPSIBLE SOILS}

De Oliveira et al. (2009). Described how the town of Solteira, Brazil, originally conceived as a temporary development, was built on deposits with a high collapse potential. As the town outgrew its expected lifetime and serviceability, the water supply and sewerage systems leaked, triggering collapses. A risk map was designed from the results of geological and engineering geological mapping, geotechnical testing, a damage register, and resident interviews. A generalized version presented as a risk register map has been used to support maintenance schedules and to raise awareness amongst those affected. 


\section{VOLCANIC HAZARDS}

Donnelly et al. (2009) presented an excellent case study of how engineering geology has proved invaluable to the mitigation of volcanic, seismic and landslide hazards on the Caribbean island of Montserrat. The Soufrière Hills volcano has been in a state of eruption for ten years, necessitating the evacuation of the majority of islanders and relocation of primary infrastructure. A review of activities since 1995 demonstrated how volcanic risk maps of the island have evolved with changing volcanic activity and population.

Williams et al. (2009) described a volcanic problem of distinctly different scale and nature to that of Montserrat, the potentially active Auckland Volcanic Field, upon which the metropolitan area of Auckland (population 1.3 million), New Zealand stands. Unlike the relatively well-defined hazards described by Donnelly et al. (2009), engineering geologists in Auckland are faced with volcanic hazards that might exhibit uncertain spatial extent and little antecedent activity. There is also the likelihood of an extended period of eruption, complex secondary hazards and a relatively unprepared urban area. To counter this potential threat, a volcanic contingency plan has been prepared. The plan includes transparent policies for a warning system, scenario-driven models of hazard and risk, protocols for civil emergency, the allocation of resources and an education programme.

\section{RADON}

Only one paper, by Miklyaev \& Petrova (2009), was presented on radon hazards. They described a new hazard map for Moscow which combines analyses of radon readings with new engineering geological maps. A survey was carried out in the 1990s that showed 68\% of city inhabitants were exposed to doses exceeding $20 \mathrm{mSv} / \mathrm{year}$ (the dose limit for professionals). Comparison between measured levels of radon and engineering geological maps of the city showed that areas of high radon readings correlated with areas underlain by clay strata. Investigation of these results revealed that the elevated readings were not because of specific radiative sources but were the effect of high background levels resulting from elevated levels within clay strata. Hence, the engineering geological map provided a good indication of the radon hazard in the city.

\section{HAZARD TO RISK}

A significant theme of the papers submitted to congress was the prevalence of risk-based methodologies and the pragmatic approach required for such research. Risk methodologies are crucial to provide comparisons of vulnerability across different hazards and at different scales. Asef (2009) presented an excellent paper that used a normalized scale that expressed the relative impact of earthquakes in different countries. He used this national earthquake vulnerability index to assess and rank 35 nations according to their vulnerability. In every analysis, Iran was demonstrably the nation most vulnerable to earthquakes. Other highly vulnerable countries in the list were China, Turkey, Italy, Japan, and Indonesia.

Many obstacles are currently in place for those attempting quantitative risk analysis. Miner \& Dahlhaus (2009) demonstrated that the wide range of methodologies available to risk assessment means that it is difficult to compare the results of different studies. Whitworth et al. (2009) showed that many methodologies are biased towards urbanised areas, to the detriment of rural locations. Asté (2009) described some of the problems of obtaining and using quantitative economic data as the basis for an assessment. He proposed that the standardised collation of such information is crucial to ensure compatibility with other assessments and application to other uses. Russian legislation will require a risk-based assessment within building design by 2010. Ragozin et al. (2009) described progress towards this and how many large or critical constructions have already been assessed in this way. However, they still highlight the significant difficulties in obtaining data for such calculations and non-standardised mechanism of calculating risks. The notion of collecting simple, standardised, updateable data to support risk assessment was further emphasised by Castro Junior (2009) and Marchiori-Faria et al. (2009). The latter of these studies also demonstrated the value of remote sensing information as a way of achieving this and of enabling simple risk zonation.

\section{URBANIZATION AS A CAUSE/TRIGGER}

Perhaps unsurprisingly, urbanization is repeatedly shown to be the cause of, or contributing factor to, many hazardous situations. Ragozin et al. (2009) described how less than $1 \%$ of urbanized areas in Russia were affected by rising groundwater levels in the late 1950s, yet currently the figure stands at about $20 \%$, and how over 40 karst collapses have been recorded in Moscow since the 1960s, whereas prior to that, they were unknown. Zhang et al. (2009) explained how water extraction, alongside undermining, has exacerbated subsidence in Nanjing, China.

According to Makovetsky (2009) leakage from water pipes from a large Russian city could total 10,000 $\mathrm{m}^{3}$ per day, and can cause significant problems. This situation has been exacerbated by the widespread cessation of maintenance in the 1990s, contributing to 960 out of 1092 cities suffering groundwater flooding. The flooding is associated with secondary hazards including suffosion, instability, chemistry changes, increased dampness, and aggressive ground conditions. Ragozin (1994) suggested that damage from suffosion, alone, can be observed in 958 towns and cities across Russia, with an approximate annual average economic cost of about \$0.5bn at 1990 prices. Khomenko (2009) related these failures directly to leakage. De Oliveira et al. (2009) described how leaking pipes (that have exceeded 
their design capacity and lifetime) have caused extensive soil collapse in Solteira, Brazil. Zuquette \& Palma (2009) demonstrated how the pattern of infiltration and overland flow in the Córrego do Vaçununga basin, São Paulo, had been altered by changes in land-use.

The seismic vulnerability of the Anthoupoli district, Athens, has been exacerbated by extensive undermining by coal extraction. Rozos \& Kynigalaki (2009) described how damage caused by earthquakes in 1981 and 1999 were more serious here than elsewhere in the region. Extensive research, including data review and widespread ground investigation, has been carried out to determine the extent of the problem. The results of this have been output as a risk map, building guidance and a list of areas where microzonation would be appropriate. This research also highlights the problems of elderly building stock which may not have always been properly maintained, a point reinforced by Petermans et al. (2009).

Some authors presented studies where significant geohazard impacts have been factored in to development plans. Huang et al. (2009) showed that the city of Kunming, China, is expected to expand from $180 \mathrm{~km}^{2}$ in 2003 to $460 \mathrm{~km}^{2}$. This will involve the 'consumption' of all available flat lying areas of lake sediments in the vicinity and will drastically change the local hydrological regime, including cutting the entire supply of water to Lake Dianchi. It is anticipated that subsidence will affect $3681 \mathrm{~km}^{2}$, severely affecting the groundwater system in the West Sichuan Plain. The effects of this subsidence will be irreversible. Similarly, the development of the Three Gorges dam has required the relocation of an entire town within an area prone to multiple hazards. Wu et al. (2009) described some of the engineering geological investigations carried out to support such development.

\section{URBAN GEOHAZARD PLANNING}

A range of methods were described by which engineering geological expertise could help planners and developers to better manage geohazards in urban areas. The largest, in terms of scale at least, was presented by Zhang et al. (2009), who described the mechanisms used to manage hazards in Nanjing City, which, in the future, is expected cover an area of $6516 \mathrm{~km}^{2}$. The city is affected by landslides, subsidence, undermining, karst and fluvial erosion. Planners have divided the city into $60001 \mathrm{~km}^{2}$ pixels, each of which is attributed in a Geographical Information System (GIS) with information on geological, soil, groundwater and hazards information. This grid was analysed using an Analytic Hierarchy Process to determine the requirements of different land uses and then by a SWOT (strengths, weaknesses, opportunities and threats) analysis to determine appropriate land-use. The city has been divided into areas which are considered suitable for industrial usage, human habitation, port/parking or commerce.

Richards \& Brynard (2009) presented an excellent paper that described the recently launched National Geohazard System for the Republic of South Africa. The system has been designed to meet the increasing needs of planners, developers and insurers in that country and utilises extensive data holdings maintained by the national geological institute/survey. Interestingly, this paper also goes into some detail regarding the technical, legal and financial issues raised by data-driven national scale assessments.

At all scales, the input of engineering geologists to urban geohazard management seems increasingly to be through the medium of GIS. Amongst the advantages of GIS described were: dealing with multiple hazards (for example, Zuquette \& Palma 2009, Ferrer et al. 2009), the joining of disparate data (for example, Ben-David \& Nachmias 2009, Saket \& Aghda 2009), the ability to incorporate a decision support or warning system (Osipov et al. 2009) and the ease with which systems can be modified or updated (Ferreira \& Pejon 2009).

Crucially, GIS allows extrapolation of scientific judgement across wider geographical areas (Baptista 2009; Ferrer et al. 2009) or the adaptation of engineering advice to answer new questions. This last point was well illustrated by Wassing \& Van Der Krogt (2009) who stressed that the final product of an engineering geological survey should not be an engineering geological report or map, but an output designed around, and often made with the input of, the enduser. In this example, thematic "subsurface suitability maps" are presented that depict the suitability of areas for a certain spatial development based upon geological and socio-economic data.

However, it was clear that GIS is just one tool available to the engineering geologist and the method is reliant upon large amounts of data and expertise (Fall et al. 2006). Although most papers in this theme did in some way use GIS, the outputs described included engineering reports, design charts, guidance documents, maps, databases and education programmes. Konno \& Nakasato (2009) described a programme of works centred on Sendai City in northeast Japan. Many developments in the city are built on soft foundations and are expected to be affected by an earthquake within the next 30 years. A major initiative to minimize the effects of future events is educating members of the general public. This has involved a series of public lectures and workshops which, over time, will build the knowledge of different sectors of the community and, importantly, give opportunities for feedback. Of particular interest has been the opportunity of participants in the scheme to create their own hazard maps - truly involving them in the hazard management process. 


\section{RETROFITTING FOR GEOHAZARDS}

Several papers presented research attempting to retrospectively adapt city infrastructure or planning policy (for example, Forster et al. 2009, Maksud Kamal \& Midorikawal 2009, De Oliveira et al. 2009). Loupasakis \& Karfakis (2009) described how many long-abandoned limestone quarries across Greece are subject to instability, usually in the form of rockfalls. Problems have arisen where these spaces have been used as public recreation areas. They highlighted a number of areas where engineering geological assessments have been required to retrospectively propose engineering or management solutions to cope with slope instability hazards.

Ground improvement in urban areas often requires special procedures that minimise disruption to surrounding developments or infrastructure. Serridge \& Synac (2009) described their Rapid Impact Compaction (RIC) technique, where a relatively light rig applies blows to the ground in rapid fashion. In the case studies presented, this meant that ground could be compacted in close proximity to existing buildings. They also suggested that the technique could be useful in areas where removal of material from the ground would mean handling contaminated material.

\section{CONCLUSIONS}

The number of papers submitted to the Congress perhaps allows for further reflection upon how engineering geology and engineering geologists are adapting to an evolving series of challenges. In many respects the papers presented reflect the themes discussed a decade ago by McCall (1998). The primary hazards include earthquakes, volcanoes, slope instability and subsidence; problems are still exacerbated by rapid development, water abstraction, undermining or neglect. A further similarity is that pervasive hazards such as shrink-swell are not highlighted - perhaps a reflection of the type of research required to investigate these hazards, or the perceived relevance of such research to conferences. New development continues to be located in open-space, on slopes or flat lying alluvium, where hazards are greatest (Schuster \& Highland 2007). Construction often encroaches upon marginal areas, for instance: coastal plains (Fall et al. 2006), unstable slopes (Zogning et al. 2007; Castro Junior et al. 2009), collapsible ground (De Oliveira et al. 2009) or karstic ground (Hu et al. 2001). Most problems still seem to arise when rapid expansion of urban areas outstrips the resources available to the planning and enforcement system (Marchiori-Faria et al. 2009, Barrett et al. 1991), developments exceed their design capacity (De Oliveira et al. 2009) or otherwise fail to account for their natural environment (see section on Urbanization). A significant challenge is posed by the planned expansion of towns into the future, where the growth is driven by political or socio-economic factors that outweigh any geoscientific arguments that can be made (for instance Huang et al. 2009, Wu et al. 2009, Zhang et al. 2009).

So what progress has taken place in the past decade? Alongside the utilization of GIS, 3D modelling software and the internet (Chacon et al. 2006; Culshaw 2005; Culshaw et al. 2006; Osipov et al. 2009), the greatest developments in engineering geology over recent years are the increasing adoption of risk methodologies. The past decade has seen a large body of work that provides an excellent framework for risk analysis, for instance Cruden \& Fell (1997); Maund \& Eddleston (1998); Aleotti \& Chowdhury (1999); Dai et al. (2002); Lee \& Jones (2004); Bird et al. (2006). A wide variety of approaches to risk analyses was demonstrated by submitted papers. These often required the combination of geotechnical data and asset data with, for instance, microzonation studies (Maksud Kamal \& Midorikawa 2009), damage registers (De Oliveira et al. 2009), disaster scenarios (Williams et al. 2009) and, to a large extent, the professional judgement of experienced scientists or engineers (Fenton 2009). Much progress is based upon the availability of exemplars of good practice. These may take the form of simple case studies, but may also include comparative studies (for instance Kwong et al. 2004) or the open publication of best practice documents such as the widely referenced Australian advice on landslide risk analysis (National Disaster Funding Programme 2007). An issue raised by several authors, including Ferreira \& Pejon, (2009) was the need to make data available to others in an accessible and useable format, though this often encounters problems of cost and copyright (Richards \& Brynard 2009). Sadly, a theme that mirrors some of the findings of the International Decade for Natural Disaster Reduction (IDNDR) is that most progress is made in the aftermath of a disaster (Donnelly et al. 2009, Forster et al. 2009) or where the hazard is well understood (Ohta et al. 2009, Williams et al. 2009). Even then, geohazard mitigation is rarely high up the political or international agenda. For instance, the IDNDR was understandably overshadowed by famine in Africa and the Balkan wars (Sudo et al. 2000).

It is useful to consider the papers submitted to conference in light of the hypothesis, put forward by Knill (2003) and developed by Culshaw (2005), that engineering geology techniques are now well developed and the profession is now moving towards a period of 'synthesis'. To achieve this, engineering geologists have to make greater efforts to communicate the nature of their findings to support and inform the decisions of other professionals, such as bankers, politicians and planners, many of whom have little interest in understanding even 'basic' concepts (Britton \& Lindsay 1995; Phien-wej et al. 2006). Crucially, this rarely involves communicating science. Instead, geohazard information must be communicated in a palatable manner that is of immediate use and immediate importance to the end-user (Rosenbaum \& Culshaw 2003). Otherwise the information will not be utilised and, crucially, the importance of the information will not be appreciated (Marker 2005). 
Mora $(2007,2009)$ suggested that to achieve the greatest impact and help the greatest number of people, the role of engineering geology must now include pro-active movement of the profession's knowledge into the realm of politics, economics and sociology. To a great extent this paradigm shift, of presenting geohazards research in terms of societal vulnerability rather than earth science, has largely been acheived within the volcanological community (Chester et al. 2002). In reviewing papers for the Congress, it appears that for radon and earthquakes hazards this shift is well underway. However, there is still significant progress to be made by engineering geologists to make the impact of landslides, erosion, subsidence, karst and collapsible ground an important and serious political and socio-economic issue.

Acknowledgements: This paper is published with the permission of the Executive Director of the British Geological Survey (NERC).

\section{REFERENCES}

Ajalloeian, R., Ghazifard. A., Hashemi M. \& Kamyab, E. 2009. Effect of stratigraphy on earth fissuring in the northern Mahyar plain, Iran. In: Culshaw, M. G., Reeves, H. J., Jefferson, I. \& Spink, T. W. (eds). Engineering geology for tomorrow's cities. Geological Society, London, Engineering Geology Special Publication **, (on CDROM insert, Paper 596).

Aleotti, P. \& Chowdhury, R. 1999. Landslide hazard assessment: summary review and new perspectives. Bulletin of Engineering Geology and the Environment, 58, (1), 21-44.

Anikeev, A. V. 2009. Destruction of aquitards, sinkhole development and land subsidence in Moscow. In: Culshaw, M. G., Reeves, H. J., Jefferson, I. \& Spink, T. W. (eds). Engineering geology for tomorrow's cities. Geological Society, London, Engineering Geology Special Publication **, (on CD-ROM insert, Paper 247).

Asef, M. R. 2009. Introducing a national earthquake vulnerability index. In: Culshaw, M. G., Reeves, H. J., Jefferson, I. \& Spink, T. W. (eds). Engineering geology for tomorrow's cities. Geological Society, London, Engineering Geology Special Publication **, (on CD-ROM insert, Paper 523).

Asté, J-P. 2009. EVARISK: methodology for the economic assessment of risk and protection efficiency evaluation. In: Culshaw, M. G., Reeves, H. J., Jefferson, I. \& Spink, T. W. (eds). Engineering geology for tomorrow's cities. Geological Society, London, Engineering Geology Special Publication **, (on CD-ROM insert, Paper 820).

Baptista, A. C., Calijuri, M. L., Loures, S. S. P. \& De Souza, P. J. A. 2009. Strategic decision analysis applied to the selection of areas for urban expansion. In: Culshaw, M. G., Reeves, H. J., Jefferson, I. \& Spink, T. W. (eds). Engineering geology for tomorrow's cities. Geological Society, London, Engineering Geology Special Publication **, (on CD-ROM insert, Paper 470).

Barrett, H. R., Fox. H. \& Stainier, L. 1991. Agadir, thirty years since the earthquake. Geography Review. 4, (3), 35-39.

Ben-David, R. \& Nachmias, D. 2009. Key factors in sustainable planning policy for the dynamic shoreline of Herzliya, central Israel. In: Culshaw, M. G., Reeves, H. J., Jefferson, I. \& Spink, T. W. (eds). Engineering geology for tomorrow's cities. Geological Society, London, Engineering Geology Special Publication **, (on CD-ROM insert, Paper 513.

Bird, J. F., Bommer, J. J., Crowley, H. \& Pinho, R. 2006. Modelling liquefaction-induced building damage in earthquake loss estimation. Soil Dynamics and Earthquake Engineering. 26, 15-30.

Britton, N. R. \& Lindsay, J. 1995. Integrating city planning and emergency preparedness: some of the reasons why. International Journal of Mass Emergencies and Disasters, 13, (1), 93-106.

Çabalar A. F. 2009. An overview of earthquake ground response analysis: a case study of Gaziantep City, Turkey. In: Culshaw, M. G., Reeves, H. J., Jefferson, I. \& Spink, T. W. (eds). Engineering geology for tomorrow's cities. Geological Society, London, Engineering Geology Special Publication **, (on CD-ROM insert, Paper 753).

Castro Junior, R. M., Souza, J. M. \& Gomes, E. S. 2009. MAPENCO Project: general results and future perspectives. In: Culshaw, M. G., Reeves, H. J., Jefferson, I. \& Spink, T. W. (eds). Engineering geology for tomorrow's cities. Geological Society, London, Engineering Geology Special Publication **, (on CD-ROM insert, Paper 169).

Chacon, J., Irigaray, C., Fernandez, T \& El Hamdouni, R. 2006. Engineering geology maps: landslides and geographical information systems. Bulletin of Engineering Geology and the Environment, 65, (4), 341-411.

Chester, D. K., Dibben, C. J. L. \& Duncan, A. M. 2002. Volcanic hazard assessment in Western Europe. Journal of Volcanology and Geothermal Research. 115, 411-435.

Cruden, D. \& Fell, R. 1997. Landslide Risk Assessment - Proceedings of the International Workshop of Landslide Risk Assessment, Honolulu, USA. A. A. Balkema, Rotterdam. 271p.

Culshaw, M. G. 2005. From concept towards reality: developing the attributed 3D geological model of the shallow subsurface: The Seventh Glossop Lecture. Quarterly Journal of Engineering Geology and Hydrogeology, 38, 231284. 
Culshaw, M. G., Nathanail, C. P., Leeks, G. J. L., Alker, S., Bridge, D., Duffy, T., Fowler, D., Packman, J. C., Swetnam, R., Wadsworth, R. \& Wyatt, B. 2006. The role of web-based environmental information in urban planning the environmental information system for planners. Science of the Total Environment, 360, 233-245.

Dai, F. C., Lee., C. F.\& Ngai, Y. Y. 2002. Landslide risk assessment and management: an overview. Engineering Geology, 64, 65-87.

De Oliveira, C. M. G., Rodrigues, R. A. \& De Lollo, J. A. 2009. Soil collapse risk map for Ilha Solteira, Brazil. In: Culshaw, M. G., Reeves, H. J., Jefferson, I. \& Spink, T. W. (eds). Engineering geology for tomorrow's cities. Geological Society, London, Engineering Geology Special Publication **, (on CD-ROM insert, Paper 196).

Donnelly, L. Jones, L., Palmer, M. \& Dilkes, C. 2009. Engineering geological and geotechnical aspects of the Soufriere Hills volcanic eruption, Montserrat. In: Culshaw, M. G., Reeves, H. J., Jefferson, I. \& Spink, T. W. (eds). Engineering geology for tomorrow's cities. Geological Society, London, Engineering Geology Special Publication **, (on CD-ROM insert, Paper 114).

Fall, M., Azzam, R. \& Noubactep, C. 2006. A multi-method approach to study the stability of natural slopes and landslide susceptibility mapping. Engineering Geology, 82, 241-263.

Fenton, C. 2009. Quantifying surface faulting hazards for lifelines crossing active faults. In: Culshaw, M. G., Reeves, H. J., Jefferson, I. \& Spink, T. W. (eds). Engineering geology for tomorrow's cities. Geological Society, London, Engineering Geology Special Publication **, (on CD-ROM insert, Paper 236).

Ferreira, M. D. \& Pejon, O. J. 2009. Erosion inventory in the region of São Pedro and Barra Bonita cities, state of São Paulo, Brazil. In: Culshaw, M. G., Reeves, H. J., Jefferson, I. \& Spink, T. W. (eds). Engineering geology for tomorrow's cities. Geological Society, London, Engineering Geology Special Publication **, (on CD-ROM insert, Paper 145).

Ferrer, M., González De Vallejo, L. I., Carlos García, J. \& Rodríguez, A. 2009. Seismic and flood hazard mapping at the local scale: Cartagena, Spain. In: Culshaw, M. G., Reeves, H. J., Jefferson, I. \& Spink, T. W. (eds). Engineering geology for tomorrow's cities. Geological Society, London, Engineering Geology Special Publication **, (on CDROM insert, Paper 760).

Forster, A., Culshaw, M. G., Gunn. D. A. \& Jackson, P. D. 2009. The mitigation of secondary seismic hazards in urban areas through the planning process with examples from Tangshan and Beijing, China. In: Culshaw, M. G., Reeves, H. J., Jefferson, I. \& Spink, T. W. (eds). Engineering geology for tomorrow's cities. Geological Society, London, Engineering Geology Special Publication **, (on CD-ROM insert, Paper 242).

Hu, R., Yeung, M., Lee, C., Wang, S. \& Xiang, J. 2001. Regional risk assessment of karst collapse in Tanghshan, China. Environmental Geology, 40, 1377-1390.

Huang, R. Q., Wang, S. J., Xu, Z. M. \& Wu, L. Z. 2009. The environmental geological issues of typical cities in southwest China and city planning. In: Culshaw, M. G., Reeves, H. J., Jefferson, I. \& Spink, T. W. (eds). Engineering geology for tomorrow's cities. Geological Society, London, Engineering Geology Special Publication **, (on CDROM insert, Paper 712).

Ghanbari, E. \& Jalili, E. 2009. Paleoseismicity and new seismicity studies in Azerbaijan and the necessity for seismic zonation. In: Culshaw, M. G., Reeves, H. J., Jefferson, I. \& Spink, T. W. (eds). Engineering geology for tomorrow's cities. Geological Society, London, Engineering Geology Special Publication **, (on CD-ROM insert, Paper 317.

Ghanbari, E., Saberi, A. R., \& Ghanbari, M.R. 2009. Neotectonic and paleoseismicity data in seismic hazard analysis of the 2006 Bam Earthquake. In: Culshaw, M. G., Reeves, H. J., Jefferson, I. \& Spink, T. W. (eds). Engineering geology for tomorrow's cities. Geological Society, London, Engineering Geology Special Publication **, (on CDROM insert, Paper 318).

Jamali, F., Fatemi Aghda, S. M. F. \& Aliyari, A. 2009. Evaluation of Seismic Sources for Hazard Assessment in the Fujairah Emirate (UAE). In: Culshaw, M. G., Reeves, H. J., Jefferson, I. \& Spink, T. W. (eds). Engineering geology for tomorrow's cities. Geological Society, London, Engineering Geology Special Publication **, (on CD-ROM insert, Paper 305).

Kanibir, A., Ulusay, R. \& Aydan, Ö. 2009. Liquefaction-induced ground deformations on a lake shore (turkey) and empirical equations for their prediction. In: Culshaw, M. G., Reeves, H. J., Jefferson, I. \& Spink, T. W. (eds). Engineering geology for tomorrow's cities. Geological Society, London, Engineering Geology Special Publication **, (on CD-ROM insert, Paper 362).

Khomenko, V. P. 2009. Suffosion hazard: today's and tomorrow's problem for cities. In: Culshaw, M. G., Reeves, H. J., Jefferson, I. \& Spink, T. W. (eds). Engineering geology for tomorrow's cities. Geological Society, London, Engineering Geology Special Publication **, (on CD-ROM insert, Paper 577).

Knill, J. 2003. Core values: the first Hans Cloos Lecture. Bulletin of Engineering Geology and the Environment, 62, 134. 
Kocbay, A. \& Orhan, T. 2009. Geotechnical properties and the liquefaction potential of the soils around Efteni Lake (Düzce-Turkey). In: Culshaw, M. G., Reeves, H. J., Jefferson, I. \& Spink, T. W. (eds). Engineering geology for tomorrow's cities. Geological Society, London, Engineering Geology Special Publication **, (on CD-ROM insert, Paper 818).

Konno, T. \& Nakasato, T. 2009. A local hazard map for the reduction of damage from earthquakes in Sendai, Japan. In: Culshaw, M. G., Reeves, H. J., Jefferson, I. \& Spink, T. W. (eds). Engineering geology for tomorrow's cities. Geological Society, London, Engineering Geology Special Publication **, (on CD-ROM insert, Paper 361).

Kwong, A. K. L., Wang, M., Lee, C. F. \& Law, K. T. 2004. A review of landslide problems and mitigation measures in Chongqing and Hong Kong: similarities and differences. Engineering Geology, 76, 27-39.

Lee, E. M. \& Jones, D. K. C. 2004. Landslide risk assessment Thomas Telford, London. 454p.

Loupasakis, C. \& Karfakis, J. 2009. Safety assessment and land planning Development of abandoned quarries in urban areas - A case study from the city of Athens, Greece. In: Culshaw, M. G., Reeves, H. J., Jefferson, I. \& Spink, T. W. (eds). Engineering geology for tomorrow's cities. Geological Society, London, Engineering Geology Special Publication **, (on CD-ROM insert, Paper 796).

Makovetsky, O. 2009. Geotechnical problems in urban terrains. In: Culshaw, M. G., Reeves, H. J., Jefferson, I. \& Spink, T. W. (eds). Engineering geology for tomorrow's cities. Geological Society, London, Engineering Geology Special Publication **, (on CD-ROM insert, Paper 449).

Maksud Kamal A. S. M. \& Midorikawa, S. 2009. Geomorphological approach for seismic microzoning within Dhaka city area, Bangladesh. In: Culshaw, M. G., Reeves, H. J., Jefferson, I. \& Spink, T. W. (eds). Engineering geology for tomorrow's cities. Geological Society, London, Engineering Geology Special Publication **, (on CD-ROM insert, Paper 457).

Marchiori-Faria, D. G., Ferreira, C. J., Fernandes-Da-Silva, P. C., Penteado, D. R. \& Cripps, J. C. 2009. Hazard mapping as part of civil defence preventative and contingency actions: a case study from Diameda, Brazil. In: Culshaw, M. G., Reeves, H. J., Jefferson, I. \& Spink, T. W. (eds). Engineering geology for tomorrow's cities. Geological Society, London, Engineering Geology Special Publication **, (on CD-ROM insert, Paper 154).

Marker, B. 2005. Foundations of the sustainable compact city. Global Built Environment Review. 4, (3), 19-23.

Maund, J. G. \& Eddleston, M. (eds). (1998). Geohazards in Engineering Geology. Geological Society, London, Engineering Geology Special Publication, 15, 441p.

McCall, G. J. H. 1998. Geohazards in the urban environment. In: Maund, J. G., Eddleston, M. (eds). Geohazards in Engineering Geology. Geological Society, London, Engineering Geology Special Publication, 15, 105-116.

Miklyaev, P. \& Petrova, T. 2009. Radon hazard in Moscow, Russia. In: Culshaw, M. G., Reeves, H. J., Jefferson, I. \& Spink, T. W. (eds). Engineering geology for tomorrow's cities. Geological Society, London, Engineering Geology Special Publication **, (on CD-ROM insert, Paper 554).

Miner, A. S. \& Dahlhaus, P. G. 2009. Geohazard risk management for municipal planning in the Corangamite region, Victoria, Australia. In: Culshaw, M. G., Reeves, H. J., Jefferson, I. \& Spink, T. W. (eds). Engineering geology for tomorrow's cities. Geological Society, London, Engineering Geology Special Publication **, (on CD-ROM insert, Paper 502).

Mo, X. \& Yuhu, W. 2009. Simulation of groundwater flow in the side slopes of a section of the Three Gorges Reservoir, Fengjie, China. In: Culshaw, M. G., Reeves, H. J., Jefferson, I. \& Spink, T. W. (eds). Engineering geology for tomorrow's cities. Geological Society, London, Engineering Geology Special Publication **, (on CD-ROM insert, Paper 644).

Mora, S. 2009. Disasters are not natural: Risk management, a tool for development. In: Culshaw, M. G., Reeves, H. J., Jefferson, I. \& Spink, T. W. (eds). Engineering geology for tomorrow's cities. Geological Society, London, Engineering Geology Special Publication **, xxx-xxx.

Mora, S. 2007. The nature of disasters: reflections on their causes and consequences in Latin America and the Caribbean (LAC). In: Proceedings of the $1^{\text {st }}$ North American Landslide Conference. Association of Environmental and Engineering Geologists; Vail, Colorado, USA, 1-30.

National Disaster Funding Programme. 2007. A national landslide risk management framework for Australia. Australian Geomechanics, 42, (1), 1-182.

Ohta, H., Hasegawa, S., Yamanaka, M. \& Saito, A. 2009. Seismic hazard in Takamatsu, Japan from a ground database system and palaeo-liquefaction studies. In: Culshaw, M. G., Reeves, H. J., Jefferson, I. \& Spink, T. W. (eds). Engineering geology for tomorrow's cities. Geological Society, London, Engineering Geology Special Publication **, (on CD-ROM insert, Paper 587). 
Osipov, V. I., Ginzburg, Al. Ab., Semenov, S. M. \& Viktorov, A. S. 2009. Developing on-line monitoring systems for geological hazards for large construction works. In: Culshaw, M. G., Reeves, H. J., Jefferson, I. \& Spink, T. W. (eds). Engineering geology for tomorrow's cities. Geological Society, London, Engineering Geology Special Publication **, (on CD-ROM insert, Paper 283).

Pergalani, F. \& Compagnoni, M. 2009. Evaluation of seismic site effects in Lombardia (Italy) by numerical analyses for urban planning. In: Culshaw, M. G., Reeves, H. J., Jefferson, I. \& Spink, T. W. (eds). Engineering geology for tomorrow's cities. Geological Society, London, Engineering Geology Special Publication **, (on CD-ROM insert, Paper 256).

Petermans, T., Devleeschouwer, X., Pouriel, F. \&and Rosset, P. 2009. Mapping the local seismic hazard in the urban area of Brussels, Belgium. In: Culshaw, M. G., Reeves, H. J., Jefferson, I. \& Spink, T. W. (eds). Engineering geology for tomorrow's cities. Geological Society, London, Engineering Geology Special Publication **, (on CD-ROM insert, Paper 424).

Phien-wej, N., Giao, P. H. \& Nutalaya, P. 2006. Land subsidence in Bangkok, Thailand. Engineering Geology, 82, 187-201.

Ragozin, A. L. 1994. Basic principles of natural hazard risk assessment and management. In: Oliveira, R., Rodrigues, L. F., Coehlo, A. G. \& Cunha, A. P. (eds). Proceedings of the $7^{\text {th }}$ International Congress of the Internatioanl Association of Engineering Geology, Lisbon, Portugal, 3, 1277-1286. A. A. Balkema, Rotterdam.

Ragozin, A. L. 2009. Geological risks, formation and assessment in urbanized territories in Russia. In: Culshaw, M. G., Reeves, H. J., Jefferson, I. \& Spink, T. W. (eds). Engineering geology for tomorrow's cities. Geological Society, London, Engineering Geology Special Publication **, (on CD-ROM insert, Paper 282).

Rebolledo, S., Lagos, J., Verdugo, R. \& Marisol Lara. 2009. Geological and geotechnical characteristics of the Pudahuel Ignimbrite, Santiago, Chile. In: Culshaw, M. G., Reeves, H. J., Jefferson, I. \& Spink, T. W. (eds). Engineering geology for tomorrow's cities. Geological Society, London, Engineering Geology Special Publication **, (on CD-ROM insert, Paper 106).

Richards, N. P. \& Brynard, H. J.2009. The development of a national geohazards programme for South Africa: why, how and when? In: Culshaw, M. G., Reeves, H. J., Jefferson, I. \& Spink, T. W. (eds). Engineering geology for tomorrow's cities. Geological Society, London, Engineering Geology Special Publication **, (on CD-ROM insert, Paper 410).

Rosenbaum, M. S. \& Culshaw, M. G. 2003. Communicating the risks arising from geohazards. Journal of the Royal Statistical Society: Series A, 2, 261-270.

Rozos, D. \& Kynigalaki, M. 2009. Subsidence phenomena in Anthoupoli district of Peristeri municipality in western Athens, Greece. In: Culshaw, M. G., Reeves, H. J., Jefferson, I. \& Spink, T. W. (eds). Engineering geology for tomorrow's cities. Geological Society, London, Engineering Geology Special Publication **, (on CD-ROM insert, Paper 262).

Ruilin, H. 2009. Urban land subsidence in China. In: Culshaw, M. G., Reeves, H. J., Jefferson, I. \& Spink, T. W. (eds). Engineering geology for tomorrow's cities. Geological Society, London, Engineering Geology Special Publication **, (on CD-ROM insert, Paper 786).

Saito, A., Yamanaka, M., Hasegawa, S, \& Hayashi, K. 2009. Evaluation of ground conditions of residential developments by microtremor characteristics \& surface-wave prospecting. In: Culshaw, M. G., Reeves, H. J., Jefferson, I. \& Spink, T. W. (eds). Engineering geology for tomorrow's cities. Geological Society, London, Engineering Geology Special Publication **, (on CD-ROM insert, Paper 597).

Saket, A. \& Aghda, M. F. 2009. Investigation of destructive and non-destructive aftershocks in important earthquakes. In: Culshaw, M. G., Reeves, H. J., Jefferson, I. \& Spink, T. W. (eds). Engineering geology for tomorrow’s cities. Geological Society, London, Engineering Geology Special Publication **, (on CD-ROM insert, Paper 763).

Schmitz, R. \& Schroeder, C. 2009. Urban site investigation in the Belgian karst belt. In: Culshaw, M. G., Reeves, H. J., Jefferson, I. \& Spink, T. W. (eds). Engineering geology for tomorrow's cities. Geological Society, London, Engineering Geology Special Publication **, (on CD-ROM insert, Paper 801).

Schuster, R. L. \& Highland, L. M. 2007. Urban landslides: socioeconomic impacts and overview of mitigative strategies - The Third Hans Cloos Lecture. Bulletin of Engineering Geology of the Environment. 66, 1-27.

Serridge, C. J. \& Synac, O. 2009. Application of the Rapid Impact Compaction (RIC) technique for risk mitigation in problematic soils. In: Culshaw, M. G., Reeves, H. J., Jefferson, I. \& Spink, T. W. (eds). Engineering geology for tomorrow's cities. Geological Society, London, Engineering Geology Special Publication **, (on CD-ROM insert, Paper 294).

Sudo, K., Kameda, H. \& Ogawa, Y. 2000. Recent History of Japan’s Disaster Mitigation and the Impact of IDNDR. Natural Hazards Review, February 2000, 10-17. 
Török, A., Xeidakis, G., Kleb, B. \& Marinos, P. G. 2009. Karst-related engineering geological hazards, a comparative study of Hungary and Greece. In: Culshaw, M. G., Reeves, H. J., Jefferson, I. \& Spink, T. W. (eds). Engineering geology for tomorrow's cities. Geological Society, London, Engineering Geology Special Publication **, (on CDROM insert, Paper 353).

Wassing, B. \& Van Der Krogt, R. 2009. Subsurface suitability maps for spatial planning. In: Culshaw, M. G., Reeves, H. J., Jefferson, I. \& Spink, T. W. (eds). Engineering geology for tomorrow's cities. Geological Society, London, Engineering Geology Special Publication **, (on CD-ROM insert, Paper 588).

Whitworth, M. R. Z, Griffiths, J. S. \& Lee, E. M. 2009. Evaluating risk in a rural environment; a case study; Sorbas, SE Spain. In: Culshaw, M. G., Reeves, H. J., Jefferson, I. \& Spink, T. W. (eds). Engineering geology for tomorrow's cities. Geological Society, London, Engineering Geology Special Publication **, (on CD-ROM insert, Paper 535).

Williams, A., Linzey, A. \& Chick, L. 2009. Auckland: a city on volcanoes. In: Culshaw, M. G., Reeves, H. J., Jefferson, I. \& Spink, T. W. (eds). Engineering geology for tomorrow's cities. Geological Society, London, Engineering Geology Special Publication **, (on CD-ROM insert, Paper 624).

Wu, X., Yu, Q., He, M., Zhao, X. \& Zhang, L. 2009. Slide mechanisms of a giant ancient slide body at Huangtupo, Badong County in the Three Gorges Reservoir area. In: Culshaw, M. G., Reeves, H. J., Jefferson, I. \& Spink, T. W. (eds). Engineering geology for tomorrow's cities. Geological Society, London, Engineering Geology Special Publication **, (on CD-ROM insert, Paper 790).

Zenóbio, A. \& Zuquette, L. 2009. Geotechnical mapping of rock masses in natural slopes using geomechanical classifications. In: Culshaw, M. G., Reeves, H. J., Jefferson, I. \& Spink, T. W. (eds). Engineering geology for tomorrow's cities. Geological Society, London, Engineering Geology Special Publication **, (on CD-ROM insert, Paper 173).

Zhang, F., Yang. Q., Jia, X., Liu, J. \& Wang, B. 2009. Land-use optimisation by geological hazard assessment in Nanjing city, China. In: Culshaw, M. G., Reeves, H. J., Jefferson, I. \& Spink, T. W. (eds). Engineering geology for tomorrow's cities. Geological Society, London, Engineering Geology Special Publication **, (on CD-ROM insert, Paper 324).

Zhou, P. 2009. Landslide hazard monitoring in China with an example from the Baota Landslide, Three Gorges area. In: Culshaw, M. G., Reeves, H. J., Jefferson, I. \& Spink, T. W. (eds). Engineering geology for tomorrow's cities. Geological Society, London, Engineering Geology Special Publication **, (on CD-ROM insert, Paper 806).

Zogning, A., Ngouanet, C. \& Tiafack, O. 2007. The catastrophic geomorphological processes in humid tropical Africa: A case study of recent landslide disasters in Cameroon. Sedimentary Geology, 199, 13-27.

Zuquette, L. V. \& Palma, J. B. 2009. Integrated assessment of infiltration and overland flow for different rainfall events. In: Culshaw, M. G., Reeves, H. J., Jefferson, I. \& Spink, T. W. (eds). Engineering geology for tomorrow's cities. Geological Society, London, Engineering Geology Special Publication **, (on CD-ROM insert, Paper 130). 


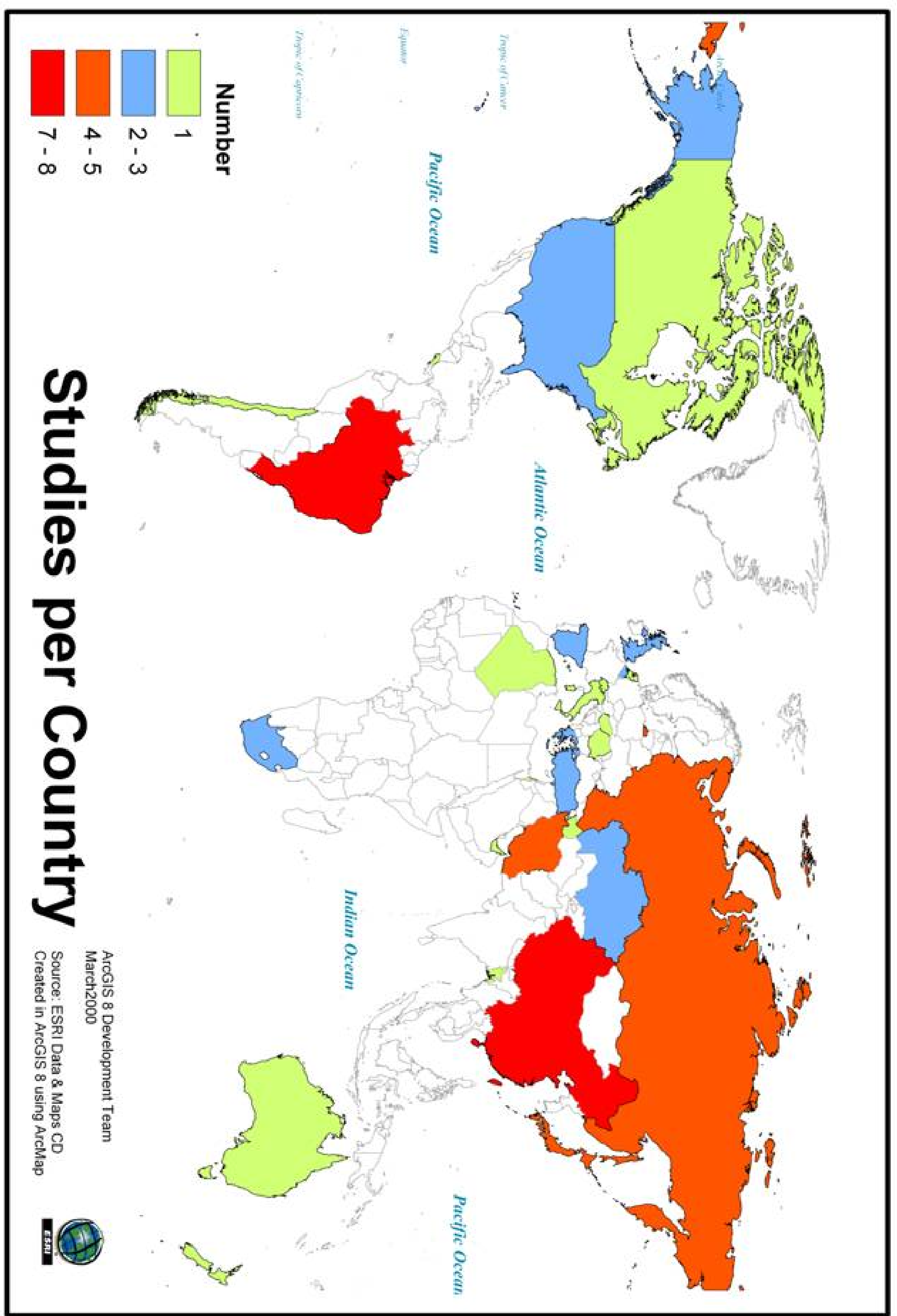

